\title{
AN ASSESSMENT OF CEREAL STUBBLE BURNING IN TURKEY
}

\section{Author(s): \\ Z. Akman}

\section{Affiliation:}

Suleyman Demirel University Faculty of Agriculture Department of Field Crops 32260 Isparta, Turkey

Email address:

zekeriyakman@sdu.edu.tr

\begin{abstract}
In Turkey, cereals are approximately 14 million hectares of sowing area by the 2014 data, about 28 million tons of the total grain production. Four cereal crops are produced on a larger scale: barley, oats, wheat and rye. Leaves, stems and roots of cereal grains, left in the field after grain harvest, is called cereal stubble. Stubble is burned widely in Turkey. Çukurova and Central Anatolian are the regions where the most intense burning stubble. Among the factors that encourage the burning process, soil preparation is difficult for the second crop will be planted after the main product cereals especially in the regions where the second crop of agricultural structures. In this study, it was evaluated the environmental results and the reasons of stubble burning, and it was compared the difference between stubble burning and leaving cereal residues in the field. It was also focused on stubble burning is necessary conditions in Turkey
\end{abstract}

\section{Keywords}

cereal, stubble burning, Turkey

\section{Introduction}

Turkey is the largest grain producer in the Middle East. Agricultural crops produced in Turkey are mainly wheat and barley. As known, cereal straw is the stem of the plant after the rest of the spike. Leaves, stems and roots of cereal grains, left in the field after grain harvest, comprise from 50 to 75 percent of the total cereal boimass produced by a season's grain crop. This cereal stubble that is left to accumulate on the ground reduces soil erosion by buffering the impact of raindrops and reducing wind speed at the soil surface. Cereal stubble also increases the water available in the soil for plant use by enhancing rainfall infiltration and reducing evaporation losses. Cereal straw accumulation and incorporation in the long term increases organic matter inputs into the soil, reduces the loss of plant nutrients and increases soil biological activity. Each type of residue makes different contributions to this process. However, despite these benefits, stubble burning is applied widely in Turkey. Çukurova and East and Central Anatolian regions are the regions where the most intense burning stubble. In Turkey, recent data showed that about 12.5 million ha area allocated to grain 'is. Sayın [1] and Korucu [2] reported that average of 1.5 - 2 tons / ha of stubble and cereal residues burned and in total 3.7 million hectares burned every year in Turkey.

In these researches, it was evaluated the environmental results and the reasons of stubble burning, and it was compared the difference between stubble burning and leaving cereal residues in the field. It was also focused on stubble burning is necessary conditions in Turkey.

\section{Reasons for farmers stubble burning}

Among the factors that encourage the burning process, soil preparation is difficult for the second crop will be planted after the main product cereals especially in the regions where the second crop of agricultural structures. Much more labor, energy and time are needed to decompose of the cereals in the soil. However, there is a huge delay even one day delay in the second crop agriculture. Therefore, farmers are becoming more willing to burn. Other reasons for burning stubble in the field can be listed as follows:

1. Easier and less costly removal of cereal stubble and residues in the soil,

2. Controlling or eliminating fungal diseases, weed seeds, and insect pest eggs,

3. Soil processing easier and less frequent

4. Fire also quickly recycles potassium, phosphorus, and other minerals back to the soil, thereby reducing the quantity of agro-chemicals that are needed on fields.

5. Lack of sufficient information on the results of the farmer's stubble burning

6. The idea that the burning of stubble improve soil fertility

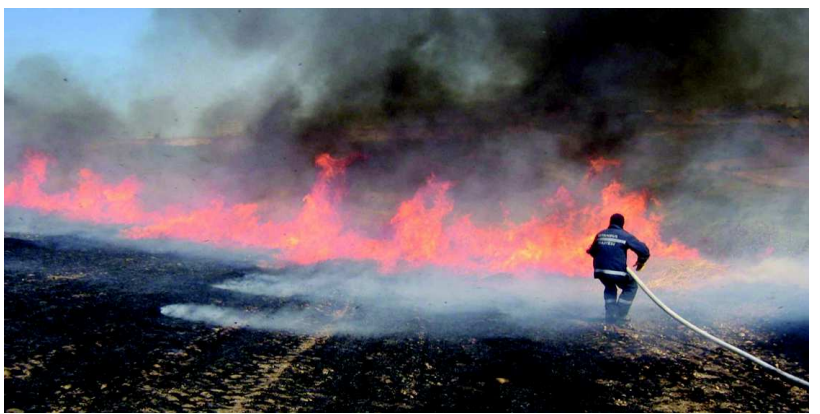

Figure 1. Firefighting efforts, which took place during the burning stubble in Aydin province of Turkey 
Also in the moist and cold of soil (eg Black Sea Region), soil organic material decomposition process takes longer. This situation negatively affects their agricultural activities of the farmers, and tillage and seedbed preparation is quite late. Therefore, in regions with cold and humid climate it is becoming mandatory stubble burning (Figure 1).

\section{Environmental and agricultural consequences of stubble burning}

Anatolia is a land where agriculture first time in the world. Rapid loss of soil due to erosion of this is regrettable. Stubble burning promotes erosion of stubble burning, adversely affect the soil moisture and temperature values. Soil erosion is a very important environmental problem of Turkey. According to statistics, an average of 743 million tons of soil are lost every year. $63 \%$ of the national territory is seen severe erosion [3]. One of the main benefits of stubble retention is reduced soil erosion. Retaining stubble decreases erosion by lowering wind speed at the soil surface and decreasing run-off. To minimise erosion approximately $50 \%$ ground cover is required and adequate stubble needs to be maintained for $6-8$ weeks following seeding [4]

Grain stubble and crop residues is a major source of soil organic matter in Anatolia. Protecting the stubble in terms of enhancing water retention ability and soil mechanical resistance is important. Cereal growing lands in which organic matter contents were poor even 40 years ago, have been ignored for decades and treated like a "stepchild" in respect to organic material application that generally suggested for vegetables and horticulture production. The long term effects of soil erosion, stubble burning, fallow and mouldboard plough tillage for years have increased the bill of this ignorance and brought the soils into "hungry" and "ill" position for organic matter content. Since soils with low organic matter content can not hold sufficient water, they can not have available conditions for planting, germination and emergence, growth and development. As known, grain stubble and crop residues is a major source of soil organic matter. Protecting the stubble in terms of enhancing water retention ability and soil mechanical resistance is important. Therefore, soils having these unfavorable conditions resist to farmers and production, limit success of cereal research and researchers, and show danger signals for future. Retaining stubble increases the input of carbon to soil. Stubble is approximately $45 \%$ carbon by weight and therefore represents a significant input of carbon to soil. When stubble is retained, the greater inputs of organic carbon to soil increase its biological fertility. Microorganisms in soil require organic carbon to obtain the $\mathrm{C}$, nutrients and energy they need to live. Labile carbon is a particularly important form of organic carbon for soil microorganisms. Management practices that increase inputs of organic carbon to soil, such as retaining stubble, can increase the number of microorganisms in soil and also cause them to be more active. Another advantage of retaining stubble is that it increases soil water content by decreasing run-off and increasing infiltration [5].

When considered in terms of air pollution issues, the scientific literature contains a great amount of information on the emissions of atmospheric pollutants from burning in various vegetation types worldwide. Field burning is a process of uncontrolled combustion during which carbon dioxide $\left(\mathrm{CO}_{2}\right)$, the principal product of the combustion, is emitted into the atmosphere along with carbon monoxide (CO), un-burnt carbon (as well as traces of methane i.e. $\mathrm{CH}_{4}$ ), nitrogen oxides $\left(\mathrm{NO}_{\mathrm{x}}\right)$ and comparatively less amount of sulphur dioxide $\left(\mathrm{SO}_{2}\right)$ [6].

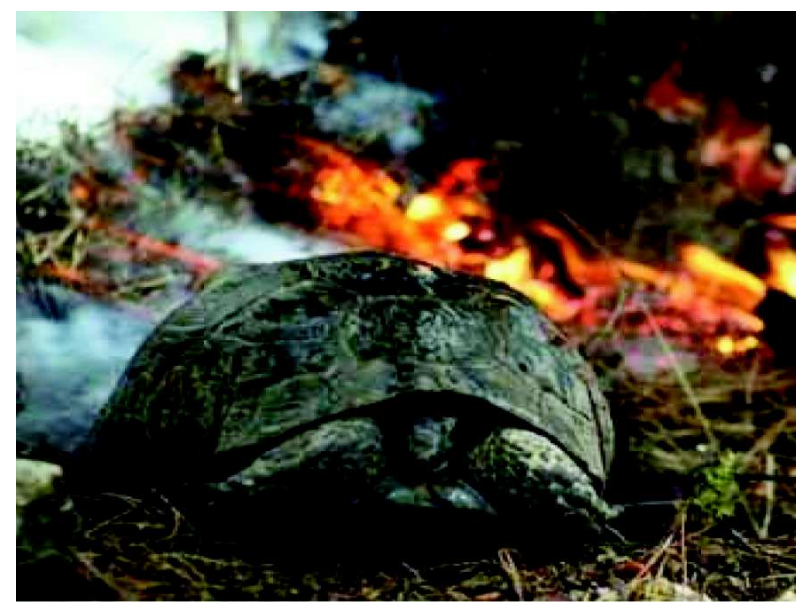

Figure 2. Stubble fires due to many wild animals are injured or die.

\section{Conclusions}

Stubble burning is a real environmental problem (Figure 2). Stubble fire on the products in neighboring fields, the orchards, the surrounding trees and fences, telephone poles, nearby settlements and particularly in forests, is particularly damaging to the woods and wooded area. Uncontrolled burning is also the leading cause of the forest fire. Stubble fires due to many wild animals are injured or die. Stubble burning, in addition to air pollution reduces visibility on roads due to the rising smoke from time to time, which leads to traffic accidents. As described above, stubble burning soil physical, chemical and biological impact negatively on the capacity. Also considering that Turkey is poor in terms of soil organic matter, stubble burning is not a rational application. Further increases the risk of erosion because it reduces the physical resistance of the soil stubble burning. To consistently get more product per unit area in both today and for the future, the main purpose of agricultural production must be improve the efficiency of our productive agricultural land and to keep in this condition.

As a result, there is little organic matter in the soil, which is more than the risk of erosion, it is difficult to controlled burning, which rapidly decompose in the field of stubble, stubble should not be burned.

\section{References}

[1.] Sayın S., 1989. Çeşitli yönleri ile anızların yakılması. Köy Hizmetleri Ankara Araştrıma Enstitüsü Yayın No. 165154.

[2.] Korucu, T., 2002. Çukurova bölgesinde II. ürün mısırın doğrudan ekim olanaklarının araştırılması. Ç.U. Fen Bilimleri Enstitüsü, Kod No. 662, Adana, Türkiye.

[3.] Doğan O.: 2011. Türkiye'de Erozyon Sorunu Nedenleri ve Çözüm Önerileri, Bilim ve Aklın Aydınlığında Eğitim, S. 134, Nisan 2011, ss. 62-69.

[4.] Leonard, 1993. Managing for stubble retention. Bulletin 4271, Department of Agriculture Western Australia.

[5.] Carson J., Flower K.: 2015. Benefits of Retaining Stubble - Western Australia. Soilquality.org., 2015.

[6.] EPA 2003. Cereal-Grain Residue Open-Field Burning Emissions Study. Washington Department of Ecology, Washington Association of Wheat Growers, U.S. Environmental Protection Agency, Region 10. Prepared by: Air Sciences Inc., 421 SW 6th Avenue, Portland. Project No. 152-02, July 2003. 